\title{
Control Versus No Control: Options for Avian Influenza H5N1 in Nigeria
}

\author{
F. O. Fasina ${ }^{1,2}$, A. C. Meseko ${ }^{2}$, T. M. Joannis ${ }^{2}$, A. I. Shittu ${ }^{2}$, H. G. Ularamu ${ }^{2}$, N. A. Egbuji ${ }^{2}$, L. K. Sulaiman ${ }^{2}$ and $^{2}$ \\ N. O. Onyekonwu ${ }^{2}$
}

1 Poultry Reference Center, Department of Production Animal Studies, Faculty of Veterinary Science, University of Pretoria, Onderstepoort 0110, South Africa

2 Viral Research Department, National Veterinary Research Institute, Vom, Nigeria

\section{Summary}

In January 2006, an outbreak of a highly pathogenic avian influenza (HPAI) was recorded in Nigeria for the first time. This present work describes an estimation of possible costs associated with a vaccination-based control policy added to other measures to restrict HPAI H5N1 virus infections. The evaluations used epidemiological and production data, including budgets necessary for the vaccine acquisition, distribution and administration in arriving at the final costs. Using decision tree and cost benefit analysis the economical benefits for Nigeria and countries with similar veterinary infrastructures, biosecurity and farming systems are calculated. The result indicated that a halting in the continued spread of the virus through effective control measure will be 52 times better than taking no action. This should help policy makers in deciding in favour of vaccination combined with other tools as an effective means of controlling avian influenza H5N1. Control of HPAI H5N1 will best be understood by policy makers in financial terms. Effective control through vaccination of poultry is much cheaper and reduces the chances of human zoonoses. Poultry vaccination combined with other control measures will be the most effective means of control in most developing economies.

\section{Introduction}

Poultry represent a major economic source of income in Nigeria. It provides $4.45 \%$ of the total animal contribution to agricultural GDP in 2004 (Central Bank of Nigeria, 2004). Ducatez et al. (2006) claimed that it is second only to oil (petroleum) in its contribution to the national GDP. It thus plays a major role in the gricultural industry in Nigeria, an industry that employs about $60 \%$ of the population.

Asian strain of highly pathogenic avian influenza (HPAI) H5N1 was reported in Africa in the beginning of January, 2006 in Nigeria (Enserink, 2006; Joannis et al., 2006). It has caused deaths of million of birds in Africa

as is the case in other affected parts of the world (Yoon et al., 2005). Nigeria had lost 945862 birds of various

species as at mid-January, 2007.

Vaccination is one of the means of controlling the further spread of avian influenza but it carries the concern of

accelerated antigenic drift and evidences of masking effective diagnosis of the virus. In recent times, the introduction and application of diagnostic methods like DIVA (differentiating infected from vaccinated animals) strategies (Capua and Marangon, 2003), and evaluation of vaccine potentials of milder strains of the viruses (Ellis et al., 2005; Subbarao and Luke, 2007) has largely resolved these issues.

Despite the above significant advances in the science of the virus, a large number of policy makers in affected countries considered the issue of vaccination with a level of uncertainty even in the face of devastation the virus is wrecking in the poultry industry. Justifying the use of vaccination in favour of potential loss of target markets is indeed a hard decision to take by these individuals. In this study, we present an economic analysis of control of avian influenza in Nigeria through vaccination combined with test/eradication policy using decision tree and cost benefit analysis (CBA) and justify the need for governments of affected countries to take informed decision in view of the continued spread of the virus.

\section{Materials and Methods}

We arrived at a two times vaccination strategy combined with test and slaughter policy over a 3-year period by using decision tree analysis (DTA) (Fig. 1) and choosing the most effective strategy for the country based on national peculiarities (poor biosecurity, unorganized farming systems and poor veterinary infrastructures).

We used Nobilis_ Influenza H5 vaccine (H5N2) A/Chicken/Mexico/232/94/CPA (Intervet International, Boxmeer, the Netherlands) as our model vaccine. Cost of unit dose of the vaccine for poultry was $\$ 0.06$ based on figures available from the producer's website (Hungerford, 2006; Intervet, 2006).

The final cost of vaccination was based on the factors of total animals to be vaccinated, frequency of the vaccination, labour and distribution costs. Vaccination administration cost (labour) of \$0.04/bird/dose (Naira 5.00) was arrived at based on prevailing market price of vaccination in Nigeria. Other costs for distribution and administration of \$156 128 (Naira 20 million) per annum was based on 2005 budget of the Federal Ministry of Agriculture and Rural Development, Nigeria (Animal Disease Control and National Veterinary Quarantine services). 


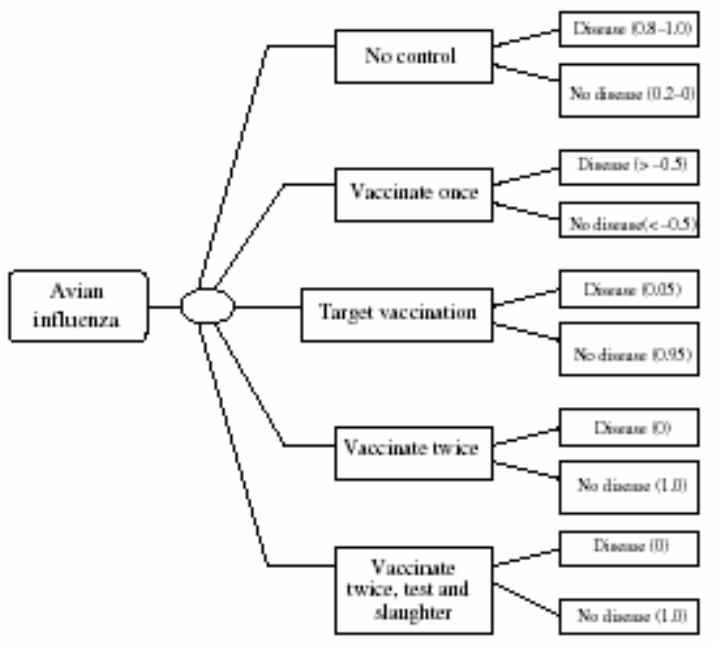

Laboratory cost was based on 2005 avian influenza research and studies budget of National Veterinary Research Institute, Nigeria while compensation and eradication estimates were based on adjusted compensation paid out to affected farmers by the government in 2006 (Nigeria Direct: Nigerian Government, 2006).

We are aware that the final cost may differ considerably from country to country but decided to use the above costing procedures which we believe may not vary much in similar developing economies. It was assumed that a $50 \%$ reduction in affected poultry population will be achieved in each year of the programme.

Graduated values for poultry population was arrived at over a 3-year period based on trends of production data available from FAO, 2006 statistical website (GLIPHA). We estimated that $70 \%$ of the poultry population will be covered at each vaccination.

Associated benefits were evaluated by using established production indices, poultry population in Nigeria and other available records. It includes reduced compensation per annum, prevention of egg production losses, regaining of regional trade in poultry meat, normalization of egg prices, evaluation of salvaged birds and prevention of redundancy of poultry facilities (Fasina et al., unpublished report). Most data were concentrated on layers (commercial and rural) as $98.1 \%$ of all HPAlaffected birds in Nigeria are laying birds and approximately $85 \%$ of the national poultry belong to the laying group of birds.

Three years for effective control was chosen based on the Vietnamese example as reported by CIDRAP News Special Report 1 and 2 (http://www.cidrap.umn.edu/cidrap/content/influenza/avianflu/news/oct2506vietsuccess/html).

All currency conversion was performed using Currency Converter on-line (http://finance.yahoo.com/currency/convert?amt= accessed on March 6, 2007). The robustness of the values used was subjected to experts' opinion.

Results

The final cost associated with the vaccination and eradication of infected population over a 3-year period will be $\$ 91868561$ (Table 1) and the final net benefit was assessed to be $\$ 5347325735$ (Table 2). Based on the prevailing discount factor in Nigeria, discounted cost and benefits were calculated for a 3-year period and the values were presented in Table 3 . The adjusted figures arrived at were used to calculate the Benefit Cost Ratio (BCR) of the project.

$$
\begin{gathered}
\text { Present Value of Benefit }\left(\mathrm{PV}_{\mathrm{B}}\right)=\frac{\text { Future Benefit (FB) }}{(1+r)^{1}} \\
\text { PresentValue of Cost (PVC) }=\frac{\text { Future Cost (FC) }}{(1+r)^{n}},
\end{gathered}
$$

where $n$ is the number of period (years) and $r$ is the periodic interest. 


$$
\begin{gathered}
\text { Gross Benefit Cost Ratio }(\mathrm{BCR})=\frac{\mathrm{PV}_{\mathrm{B}}}{\mathrm{PV}_{\mathrm{C}}} \\
\text { Calculated } \mathrm{BCR}=\frac{4267315737}{82751364} \\
\mathrm{BCR}=\mathbf{5 1 . 5 7 .}
\end{gathered}
$$

\begin{tabular}{|c|c|c|c|c|c|c|}
\hline Year & $\begin{array}{l}\text { Poultry } \\
\text { estimates } \\
\text { (headcount) }\end{array}$ & $\begin{array}{l}\text { Vaccinated } \\
\text { population } \\
(70 \%)\end{array}$ & $\begin{array}{l}\text { Cost of vaccination } \\
\text { (two doses given } \\
4 \text { weeks apart) (\$) }\end{array}$ & $\begin{array}{l}\text { Labour, distribution } \\
\text { and administration } \\
\text { costs (\$) }\end{array}$ & $\begin{array}{l}\text { Compensation } \\
\text { and } \\
\text { eradication (\$) }\end{array}$ & $\begin{array}{l}\text { Associated } \\
\text { laboratory } \\
\text { cost (\$) }\end{array}$ \\
\hline $0(2006)$ & 156800000 & 109760000 & 13171200 & 8936928 & 11076044 & 155642 \\
\hline $1\langle 2007)$ & 163934400 & 114754080 & 13770490 & 9336454 & 5538022 & 116732 \\
\hline $2(2008)$ & 171393415 & 119975390 & 14397047 & 9754159 & 5538022 & 77821 \\
\hline $3(2009)$ & 179191815 & - & - & - & - & - \\
\hline
\end{tabular}

Table 1. Costs associated with a vaccination and test and slaughter policy

Cost of vaccine per bird per two doses is $\$ 0.12$; cost of vaccine administration is $\$ 0.04$ per bird; cost of distribution and other administration is $\$ 156128$ per annum; compensation was paid at $\$ 11.673$ per chicken; total birds lost as at January 2007 was 945862 ; associated laboratory cost is $\$ 156128$ which will decrease by $25 \%$ per annum.

Table 2. Associated benefits of a vaccination with test and slaughter policy

\begin{tabular}{lllllll}
\hline & $\begin{array}{l}\text { Reduced } \\
\text { compensation } \\
\text { Year }\end{array}$ & $\begin{array}{l}\text { Prevention of } \\
\text { egg losses } \\
\text { (\$) }\end{array}$ & $\begin{array}{l}\text { Regaining of } \\
\text { external trade } \\
\text { (\$) }\end{array}$ & $\begin{array}{l}\text { Normalty in } \\
\text { egg prices } \\
\text { (\$) }\end{array}$ & $\begin{array}{l}\text { Value of } \\
\text { salvaged bircls } \\
\text { (\$) }\end{array}$ & $\begin{array}{l}\text { Prevention of } \\
\text { faci ies redundancy } \\
\text { (\$) }\end{array}$ \\
\hline $0(2006)$ & - & - & - & - & - & - \\
$1(2007)$ & 5538022 & 9785968 & 393120000 & 1327794875 & 6649410 & 738378 \\
$2(2008)$ & 2769011 & 4892984 & 393120000 & 1388431539 & 3324705 & 369189 \\
$3(2009)$ & 2769011 & 4892984 & 393120000 & 1456315773 & 3324705 & 369189 \\
\hline
\end{tabular}

Calculations were based on 284 eggs per bird per annum; Chicken eggs sell for $\$ 2.19$ per tray of 30 eggs; Poultry Association claimed export of 12000 tons of poultry meat per month to regional markets at $\$ 2.73$ per kilogram; Mean observed reduction in egg price during peak infection of HPAl was $\$ 1.01$; value of chicken is $\$ 7.03$; average cost of facility for 1000 chicken per annum is $\$ 780.64$.

Table 3. Costs and benefits associated with the control programme over a 3-year period

\begin{tabular}{lllllllll}
\hline Year & $\begin{array}{l}\text { Discount } \\
\text { factor }(0.12)\end{array}$ & \multicolumn{1}{c}{ Cost (\$) } & Benefit (\$) & $\begin{array}{l}\text { Net cash flow } \\
\text { (\$) }\end{array}$ & $\begin{array}{l}\text { Cumulative } \\
\text { cash flow (\$) }\end{array}$ & $\begin{array}{l}\text { Discounted } \\
\text { cash flow (\$) }\end{array}$ & $\begin{array}{l}\text { Discounted } \\
\text { cost (\$) }\end{array}$ & $\begin{array}{l}\text { Discounted } \\
\text { benefit (\$) }\end{array}$ \\
\hline $0(2006)$ & 1.00 & 33339814 & 0 & -33339814 & -33339814 & -33339814 & 33339814 & \\
$1(2007)$ & 0.89 & 28761698 & 1743626653 & 1714864955 & 1711530974 & 1526229810 & 25597911 & 1551827721 \\
$2(2008)$ & 0.80 & 29767049 & 1742907420 & 1713140371 & 3424671345 & 1370512297 & 23813639 & 1394325936 \\
$3(2009)$ & 0.71 & 0 & 1860791662 & 1860791662 & 5285463007 & 1321162080 & 0 & 1321162080 \\
Totals & & 91868561 & 5347325735 & 5255457174 & 10388325512 & 4184564373 & 82751364 & 4267315737 \\
\hline
\end{tabular}

\section{Discussion and Conclusion}

From the present study, we applied DTA and CBA to determine the effect of control and no control policy on the management and eradication of avian influenza in Nigeria. Based on our estimates, it was revealed that the benefit cost ratio (BCR) of our choice of control measure was approximately 52 times better than a no control policy from the economic point of view. If implemented in a strict sense, the control measures will begin to yield quantifiable result within a year of its operation and within the same year, it would have fully justify the financial cost associated with the implementation of the 3-year programme.

Although cheaper alternatives were identified in the DTA, the nature of the poultry industry in Nigeria as well as several other developing and transiting countries makes the chosen method the most suitable.

It is known that enhanced biosecurity, stamping out, movement restrictions and effective surveillance are able to minimize the risk of avian influenza (Capua and Marangon, 2003), those measures alone will not be sufficient for the control of avian influenza in 
countries like Nigeria; and thus the use of vaccination as an additional control measure will be well justified under the circumstances of poor veterinary infrastructure, poor biosecurity and unorganized farming system that presently exist in most underdeveloped and developing economies.

The use of vaccination as a control option may restrict external trade in poultry and poultry products, but it will help in protecting the industry from eventual collapse as it reduce virus shedding (Capua and Marangon, 2006; Cauthen et al., 2000) that may be associated with a no control policy, and considering the economic benefit of control through vaccination combined with test and slaughter policy, it will be a worthwhile venture. Further benefits that are associated with good control measures including environmental, ecological and medical have been evaluated and quantified by previous workers (Bridges, 2000; Mullooly et al., 1994; Bloom et al., 2005).

We agreed that our study has certain limitations and economic assumptions, which is partly explained by the weak surveillance and reporting structures in Nigeria, as well as lack of readily available data, this model will be beneficial to policy makers in using informed judgment in arriving at key decision. It will also serve as baseline data for future economic analyses.

Costs associated with the intangible factors in our estimates and assumptions may vary widely with changes in disease outbreak patterns, spreads and infectiousness. Other workers had similarly identified uncertainties associated with disease situations (Ramsay et al., 1999; Horst et al., 1999).

In conclusion, the implementation of a good vaccination programme with test and control policy will be of utmost benefit to a country like Nigeria.

References

1. Bloom, D. E., D. Canning, and M. Weston, 2005: The value of vaccination. World Economics 6, 15-39.

2. Bridges, C. B., 2000: Effectiveness and cost-benefit of influenza vaccination of healthy working adults: a randomized controlled trial. JAMA 284, 1655-1663.

3. Capua, I., and S. Marangon, 2003: The use of vaccination as an option for the control of avian influenza. Proceedings of the 71st General Session of the World Organisation for Animal Health (OIE), Paris, 18-23 May, 2003, 71SG/12/CS3E.

4. Capua, I., and S. Marangon, 2006: Control of avian influenza in poultry. EID 12, 1319-1324.

5. Cauthen, A. N., D. E. Swayne, S. Schultz-Cherry, M. L. Purdue, and D. L. Suarez, 2000: Confirmed circulation in China of highly pathogenic avian influenza viruses encoding the haemagglutinin gene associated with the 1997 H5N1 outbreak in poultry and human. J. Virol. 74, 6592-6599.

6. Central Bank of Nigeria, 2004: Annual Report and Statement of Account. Central Bank of Nigeria, Abuja.

7. Ducatez, M. F., C. M. Olinger, A. A. Owoade, S. De Landtsheer, W. Ameerlaan, H. G. M. Niesters, A. D. M. E. Osterhaus, R. A. M. Fouchier, and C. P. Muller, 2006: Multiple introduction of H5 N1 in Nigeria. Nature 442, 37.

8. Ellis, T. M., L. D. Sims, H. K. H. Wong, L. A. Bissett, K. C. Dyrting, K. W. Chow, and C. W. Wong, 2005: Evaluation of vaccination to support control of H5N1 avian influenza in Hong Kong. In: Schrijver, R. S., and G. Koch (eds), Wageningen UR Frontis Series: Avian Influenza, Prevention and Control. Springer, Dordrecht; London.

9. Enserink, M., 2006: Avian influenza: H5 N1 moves into Africa, European Union, Deepening Global Crisis. Science 311, 932a. FAO, 2006: Global Livestock Production and Health Atlas. Available at: http://www.fao.org/ag/aga/glipha/index.jsp (accessed 3rd March 2007).

10. Gao, W., C. Adam, A. C. Soloff, X. Lu, A. Montecalvo, D. C. Nguyen, Y. Matsuoka, P. D. Robbins, D. E. Swayne, R. O. Donis, J. M. Katz, S. M. Barratt-Boyes, and A. Gambotto, 2006: Protection of mice and poultry from lethal H5N1 avian influenza virus through adenovirus-based immunization. J. Virol. 80, 1959-1964.

11. Hoelscher, M. A., S. Garg, D. S. Bangari, J. A. Belser, X. Lu, I. Stephenson, R. A. Bright, J. M. Katz, S. K. Mittal, and S. Sambhara, 2006: Development of adenoviral-vector-based pandemic influenza vaccine against antigenically distinct human H5N1 strains in mice. Lancet 367, 475-481.

12. Horst, H. S., C. J. de Vos, F. M. H. Tomassen, and J. Stelwagen, 1999: The economic evaluation of control and eradication of epidemic livestock diseases. Rev. Sci. Tech. Off. Int. Epizoot. 18, 367-379.

13. Hungerford, J, 2006: Q\&A About Bird Flu Vaccine For Poultry. Available at: http://www.medicalnewstoday.com/medicalnews. php?newsid=39771 accessed 26th February 2007).

14. Intervet_, 2007: Avian Influenza Disease and Control Strategies. Available at: http://www.avian-influenza.com (accessed 4th March 2007).

15. Joannis, T., L. H. Lombin, P. De Benedictis, G. Cattoli, and I. Capua, 2006: Confirmation of H5 N1 avian influenza inm Africa. Vet. Rec. 158, 309-310.

16. Mullooly, J. P., M. D. Bennett, M. C. Hornbrook, W. H. Barker, W. W. Williams, P. A. Patriaca, and P. H. Rhodes, 1994: Influenza vaccination programs for elderly persons: cost effectiveness in a health maintenance organization. Ann. Intern. Med. 121, 947-952.

17. Nigerian Government, 2006: Year 2005 Budget. Available at: http://www.nigeria.gov.ng/dbudget2005.pdf (accessed 21st October 2006).

18. Ramsay, G. C., P. Philip, and P. Riethmuller, 1999: The economic implications of animal disease control at the national level. Rev. Sci. Tech. Off. Int. Epizoot. 18, 343-356.

19. Subbarao, K., and C. Luke, 2007: H5N1 viruses and vaccines. PLoS Pathog. 3, e40.

20. Yoon, H., C. K. Park, H. M. Nam, and S. H. Wee, 2005: Virus spread pattern within infected chicken farms using regression model: the 2003-2004 HPAl epidemic in the Republic of Korea. J. Vet. Med. B 52, 428-431. 